\title{
GEOMECHANICKÉ VLASTNOSTI NEOGENNÍCH JÍLŮ NA ÚZEMÍ MĚSTA BRNA
}

\author{
Geomechanical properties of Neogene clay soils in the Brno area
}

Petra Fürychová1,2, Rostislav Melichar'2, Ivan Poull,

'Česká geologická služba, Leitnerova 22, 65859 Brno; e-mail: petra.furychova@geology.cz

2 Ústav geologických věd PřF MU, Kotlárská 2, 61137 Brno

(24-32 Brno, 24-34 Ivančice, 24-41 Vyškov, 24-43 Šlapanice)

Key words: Carpathian Foredeep, Miocene, Neogene clay, Geomechanical properties

Abstract

Neogene clays in Brno area are formations belonging to the Carpathian Foredeep Basin. They form common foundation soil in this strongly urbanized area. Due to their specific mechanical characteristics and a large spreaded area in Brno a detailed study of the geomechanical properties of Neogene clays has practical importance for engineering geology and geotechnics. There are compared analyzed data of physical and mechanical properties from 81 engineering-geological reports at the Brno agglomeration (452 samples of Neogene clays from 180 bores). There are presented the anomalous, distant values, arithmetic average and mode of the Neogene clays. On the basis of assumed data from various geological-engineering reports are defined typical characteristics of these soils. Neogene clays are fine-grained cohesive soils. In terms of ČSN EN ISO 14688-1, 14688-2 and UCSC classification these are classified mainly as clay or silt with high, very high or extremely high plasticity. It is usually with high plasticity index, stiff and very stiff consistence and with medium and high undrained shear strength. Low values of cohesion could be related to soil damaged by landslide movements. Due to its unfavourable properties, Neogene clays refer to partly suitable environment for shallow strip-foundations mainly due to the possibilities of volume changes in the subground. For all projection of foundations, there should be paid special attention to good engineering-geological investigation at real site.

\section{Úvod}

Jíly a jílovité zeminy mají díky svým specifickým vlastnostem a odlišnému mechanickému chování zvláštní postavení v problematice mechaniky zemin a je nutno věnovat jim zvýšenou pozornost. Tyto zeminy, které jsou tvořeny hlavně neogenními jíly karpatské předhlubně, jsou na území brněnské aglomerace častými základovými půdami.

V současnosti není možné používat směrné normové charakteristiky za dnes již zrušené ČSN 73 1001, které byly užívány po řadu let pro geotechnické výpočty jako např stanovení únosnosti základových půd a pro dimenzování základových konstrukcí. Hlavní nepříznivá vlastnost jílů jako základových půd je jejich objemová nestálost - při zvyšování vlhkosti dochází $\mathrm{k}$ jejich bobtnání, zatímco při vysušování se smrštují. Praktickým důsledkem je vznik poruch staveb na těchto objemově nestálých zeminách.

\section{Označení „neogenní jíly“}

$\mathrm{Na}$ území města Brna se $\mathrm{v}$ rámci neogenních sedimentů karpatské předhlubně můžeme setkat s různými jíly, které se liší nejenom svým stárím (ottnang, karpat a spodní baden), ale i svým litologickým složením.

Jíly ottnangu jsou převážně šedé až zelenošedé, nevápnité jíly, často s prachovitou i písčitou příměsí. Jedná se o sladkovodní sedimenty, které jsou produktem jezerní sedimentace. Jíly karpatského stáŕí jsou hnědošedé až šedé, místy pestře smouhované. Bývají proměnlivě písčité, slabě vápnité, často vrstevnaté a jsou marinního původu. Plošně i vertikálně nejrozšiřrenější jsou jíly spodnobadenské. Jedná se o šedé, šedomodré až šedozelené vápnité prachovité jíly s vložkami písků, často nazývané starým označením „tégly“. Uložily se během transgrese spodnobadenského moře (Hanžl et al. 2011; Buriánek et al. 2013).

V inženýrskogeologických průzkumech nebývá stáří jílů vyčleněno a jsou označovány pouze jako neogenní, př́padně bývají automaticky zařazeny mezi spodnobadenské „tégly“. Opodstatněnost tohoto přiřazení je dána dominantním plošným rozšířením spodnobadenských jílů oproti ostatním.

Nepřesné časové zařazení jílů je způsobeno obtížnou identifikací, kdy jednotlivé jíly nejsou lehce vizuálně odlišitelné a pro inženýrskogeologickou praxi není detailní zařazení natolik zásadní. Proto ani na základě revize popisů z IG průzkumů není možno snadno zpětně zařadit zastižené jíly do správného stupně stárí. Tento text proto prezentuje souborně vlastnosti neogenních jílů a nenárokuje si odlišení pro jíly různého stáří v rámci neogénu.

\section{Metodika}

Pro rozšíření znalosti základních geomechanických charakteristik neogenních jílů byl vytvořen rozsáhlý soubor hodnot fyzikálně-mechanických vlastností z rešeršních údajů z 81 zpráv inženýrskogeologických průzkumů na území brněnské aglomerace. Celkem byla zpracována data ze 180 vrtů, $\mathrm{v}$ rámci nichž byly provedeny zkoušky na 452 vzorcích jílů $\mathrm{z}$ hloubek od 1 metru až do 60 metrů 


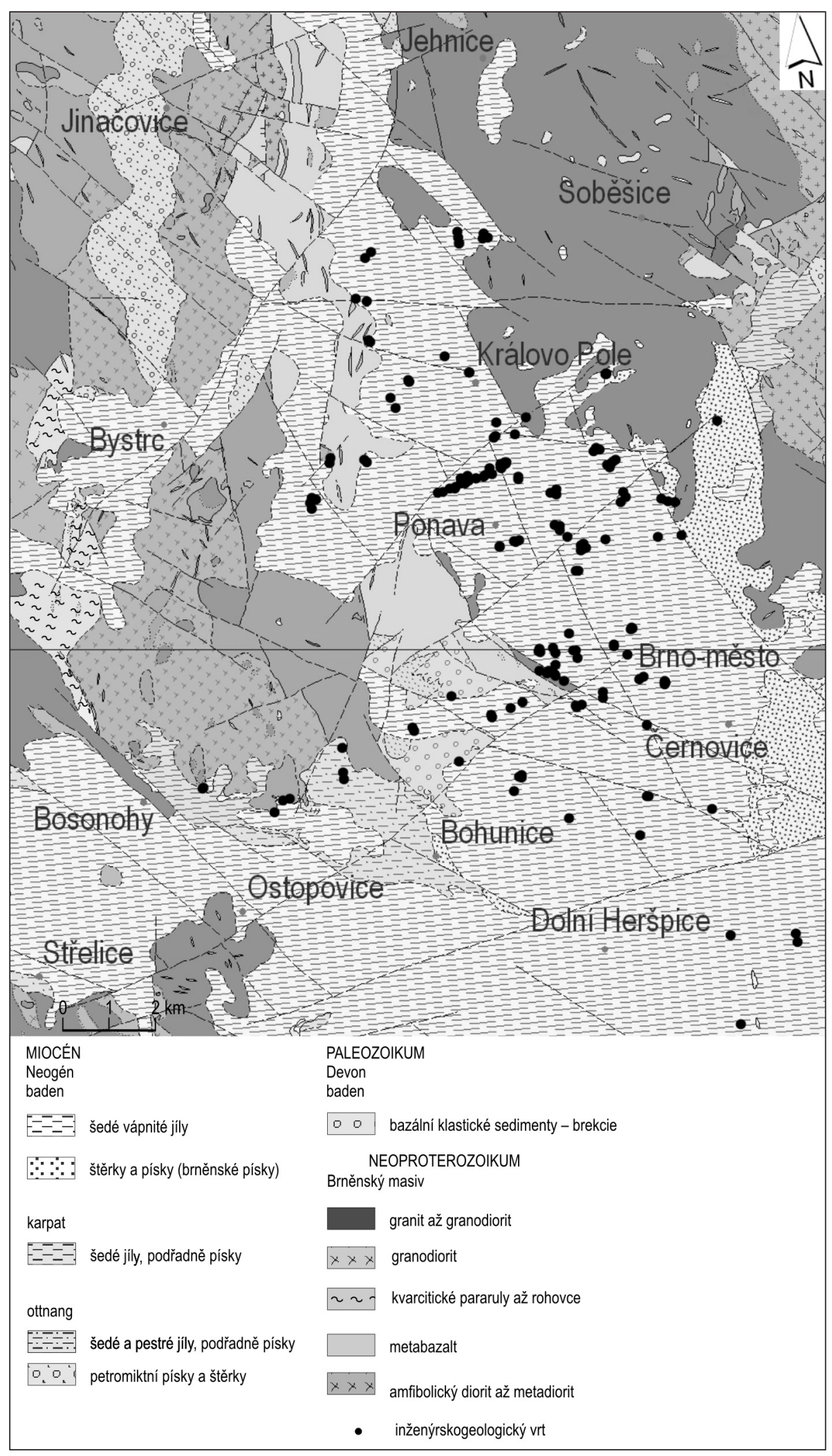

Obr. 1: Rozšíření sedimentů karpatské předhlubně na území města Brna s vyznačenou polohou vrtů, z nichž byly analyzovány vzorky neogenních jílů.

Fig. 1: Extension of the sediments of the Carpathian foredeep in Brno area. There are marked locations of drills from which were analyzed Neogene clays.

pod terénem. Lokalizace vrtů, z nichž pochází analyzované jíly v rámci prostoru města Brna, je zobrazena na obrázku 1.

Analýza dat byla zaměřena na sledování základních fyzikálních a indexových vlastností (w vlhkost, konzistenč- ní meze $\mathrm{w}_{1}$ a $\mathrm{w}_{\mathrm{p}}$, index plasticity $I_{p}$, index konzistence $I_{c}$, objemová hmotnost $\rho$, zdánlivá hustota pevných částic $\rho$, objemová hmotnost suché zeminy $\rho_{\mathrm{d}}$, pórovitost $\mathrm{n}$, stupeň nasycení $S_{r}$ ) a pevnostní charakteristiky (totální soudržnost $\mathrm{c}_{\mathrm{u}}$, totální úhel vnitřního tření $\varphi_{\mathrm{u}}$, efektivní soudržnost $c^{\prime}$, efektivní úhel vnitřního tření $\left.\varphi^{\prime}\right)$. Všechny sledované vlastnosti jsou uvedeny v tabulkách 1 a 2.

Pro získání reprezentativních hodnot neogenních jílů byly sestaveny histogramy. Histogram je sloupcový diagram, který na ose x zobrazuje intervaly tzv. třídy zjištěných hodnot, zatímco osa y znázorňuje absolutní počet vzorků, které těchto hodnot nabývají. Na základě nich byly odečteny širší rozsahy nejčastěji zastoupených hodnot a byl dopočten modus.

Uvedeny jsou minimální i maximální hodnoty jednotlivých vlastností (anomální hodnoty). Pro jednotlivé parametry je uveden aritmetický průměr, který se stal častým nástrojem při vyhodnocování vlastností v inženýrsko-geologických zprávách. Vhodnost použití aritmetického průměru je však omezená (zahrnuje v sobě výrazný vliv odlehlých hodnot souboru dat), proto jsou v tabulkách zobrazeny i výsledky dopočtených modů $\mathrm{z}$ vytvořených histogramů. Modus charakterizuje typickou hodnotu souboru dat a byl vypočítán na základě nejčetněji zastoupených tříd a představuje tak jakousi typickou „nejčastější hodnotu pro brněnský neogenní jíl.

$$
\hat{\mathrm{x}}=\mathrm{d}_{\mathrm{m}}+\frac{\mathrm{n}_{\mathrm{m}}-\mathrm{n}_{\mathrm{m}-1}}{2 \mathrm{n}_{\mathrm{m}}-\mathrm{n}_{\mathrm{m}-1}-\mathrm{n}_{\mathrm{m}+1}} \mathrm{~h}
$$

Kde x̂ je modus, $\mathrm{d}_{\mathrm{m}}$ je dolní mez modální třídy, $\mathrm{n}_{\mathrm{m}}$ je četnost modální třídy, $\mathrm{n}_{\mathrm{m}-1}$ je četnost třídy předcházející modální třídě, $\mathrm{n}_{\mathrm{m}+1}$ je četnost třídy následující po modální trrídě, $h$ je četnost třídy. 
Tab. 1: Fyzikální a indexové vlastnosti neogenního jílu na území města Brna.

Tab. 1: Physical and index properties of Neogene clay in Brno area.

\begin{tabular}{|c|c|c|c|c|c|c|c|c|c|c|}
\hline & $\begin{array}{c}\mathrm{W} \\
{[\%]}\end{array}$ & $\begin{array}{c}\mathrm{W}_{1} \\
{[\%]}\end{array}$ & $\begin{array}{l}\mathrm{w}_{\mathrm{p}} \\
{[\%]}\end{array}$ & $\begin{array}{c}\mathrm{I} \\
{[\%]}\end{array}$ & $\begin{array}{c}I_{c} \\
{[-]}\end{array}$ & $\begin{array}{c}\rho \\
{\left[\mathrm{kg} \cdot \mathrm{m}^{-3}\right]}\end{array}$ & $\begin{array}{c}\rho_{\mathrm{d}} \\
{\left[\mathrm{kg} \cdot \mathrm{m}^{-3}\right]}\end{array}$ & $\begin{array}{c}\rho_{\mathrm{s}} \\
{\left[\mathrm{kg} \cdot \mathrm{m}^{-3}\right]}\end{array}$ & $\begin{array}{c}\mathrm{n} \\
{[\%]}\end{array}$ & $\begin{array}{c}\mathrm{S}_{\mathrm{r}} \\
{[\%]}\end{array}$ \\
\hline minimální hodnota & 9,6 & 28,02 & 8 & 8,78 & 0,55 & 1676 & 1131 & 2581 & 31 & 73 \\
\hline aritmetický průměr & 31,7 & 74,5 & 31,0 & 43,4 & 1,0 & 1880,3 & 1438,1 & 2728,1 & 47,8 & 94,2 \\
\hline modus & 34,9 & 78,4 & 31,9 & 44,1 & 1,0 & 1868,3 & 1396,0 & 2722,0 & 48,5 & 98,7 \\
\hline
\end{tabular}

Tab. 2: Parametry smykové pevnosti neogenního jílu na území města Brna.

Tab. 2: Shear strength parameters of the Neogene clay in Brno area.

\begin{tabular}{|l|r|r|r|r|}
\hline & $\begin{array}{c}\mathrm{c}_{\mathrm{u}} \\
{[\mathrm{kPa}]}\end{array}$ & $\begin{array}{c}\varphi_{\mathrm{u}} \\
{\left[{ }^{\circ}\right]}\end{array}$ & $\begin{array}{c}\mathrm{c}^{\prime} \\
{[\mathrm{kPa}]}\end{array}$ & $\begin{array}{c}\varphi^{\prime} \\
{\left[{ }^{\circ}\right]}\end{array}$ \\
\hline počet vzorků & 95 & 95 & 56 & 56 \\
\hline minimální hodnota & 4,0 & 0,0 & 0,0 & 8,0 \\
\hline maximální hodnota & 400,0 & 37,6 & 104,0 & 30,8 \\
\hline aritemtický prům̌̌r & 103,3 & 9,3 & 31,5 & 18,4 \\
\hline modus & 86,1 & 3,6 & 23,1 & 17,6 \\
\hline nejčastější rozsah & $75,1-150,0$ & $0,1-10,0$ & $4,1-40,0$ & $10,1-25,0$ \\
\hline
\end{tabular}

\section{Výsledky}

V tabulce 1 jsou zobrazeny zjištěné hodnoty fyzikálních a indexových vlastností neogenního jílu na území Brna. Tyto vlastnosti charakterizují jednotlivé fáze $\mathrm{v}$ zemině (voda, vzduch, pevné částice). Zkoušky stanovující tyto parametry jsou časté, proto je vyhodnocený soubor dat rozsáhlý. Pokud je nutné použít pro stanovení typických hodnot brněnských jílů jednu hodnotu, lze užít jak aritmetického průměru, tak modu. Díky rozsáhlejšímu souboru
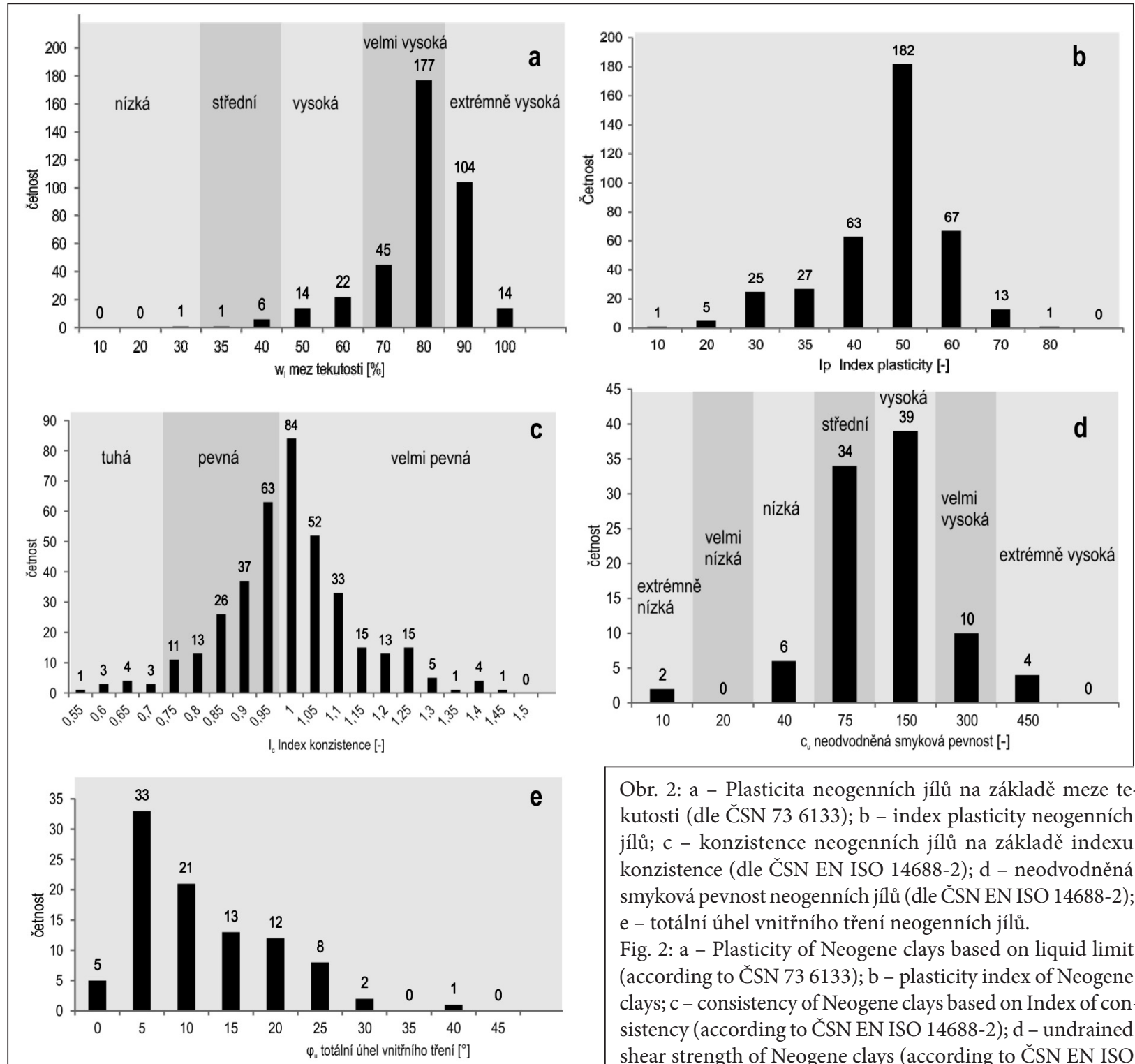

Obr. 2: a - Plasticita neogenních jílů na základě meze tekutosti (dle ČSN 73 6133); b - index plasticity neogenních jílů; c - konzistence neogenních jílů na základě indexu konzistence (dle ČSN EN ISO 14688-2); d - neodvodněná smyková pevnost neogenních jílů (dle ČSN EN ISO 14688-2); e - totální úhel vnitřního tření neogenních jílů.

Fig. 2: a - Plasticity of Neogene clays based on liquid limit (according to ČSN 73 6133); b - plasticity index of Neogene clays; c - consistency of Neogene clays based on Index of consistency (according to ČSN EN ISO 14688-2); d - undrained shear strength of Neogene clays (according to ČSN EN ISO 14688-2); e - friction angle for total stress conditions. 
(stovky vzorků) dat není aritmetický průměr extrémně ovlivněn odlehlými hodnotami a poměrně koresponduje s hodnotou modu.

Na základě zpracovaných hodnot lze konstatovat, že neogenní jíly na území města Brna jsou zeminy dosahující obvykle hodnot vlhkosti w 30,1-39,0\%. Mez tekutosti $\mathrm{w}_{1}$ se nejčastěji pohybuje $\mathrm{v}$ rozsahu $60,1-80,0 \%$ a mez plasticity $\mathrm{w}_{\mathrm{p}} 24,1-38,0 \%$. Z porovnání vlhkosti a Atterbergových mezí vyplývá, že vlhkost neogenních jílů se často pohybuje nad mezí plasticity, jíly jsou tedy zpravidla $\mathrm{v}$ plastickém stavu. Dle klasifikace plasticity na základě meze tekutosti $\mathrm{w}_{1}$ (ČSN 73 6133) řadíme neogenní jíly mezi velmi vysoce až extrémně vysoce plastické zeminy (viz obr. 2a).

Index plasticity I (viz obr. 2b) prokazuje, že neogenní jíly bývají v plastickém stavu obvykle při vlhkostech 35,1-60,0\%. Tyto vysoké hodnoty I potvrzují značné zastoupení jílových minerálů, které způsobuje vysokou plasticitu. Stupeň konzistence I bývá 0,81-1,11 ( obr. 2c), proto jíly obvykle náleží konzistenci pevné až velmi pevné (ČSN EN ISO 14688-2).

Objemová hmotnost $\rho$ se nejčastěji pohybuje v rozsahu 1 781-1960 kg.m-3, objemová hmotnost suché zeminy $\rho_{\mathrm{d}} 1281-1520 \mathrm{~kg} \cdot \mathrm{m}^{-3}$ a zdánlivá hustota pevných částic $\rho_{\mathrm{s}}$ je od 2701 do $2750 \mathrm{~kg} . \mathrm{m}^{-3}$. Jíly mají poměrně vysokou pórovitost n $44,1-52,0 \%$ a jsou vysoce nasycené, často i zcela nasycené vodou $S_{r}$ od 92,1 do $100 \%$.

Dle norem ČSN EN ISO 14688-1 a 14688-2 jsou neogenní jíly jemnozrnné zeminy patřící převážně do zemin typu $\mathrm{Cl}$ (jíl) a siCl (prachovitý jíl), při vyšším zastoupení písčité složky pak saCl (písčitý jíl). Dle mezinárodní klasifikace UCSC („Unified soil classification system“) dřive zahrnuté v ČSN 731001 (dnes neplatná) a nyní používané v rámci ČSN 736133 se jedná o jemnozrnné zeminy tříd F7 a F8. Některé vzorky byly zařazeny k hlínám - hlína $\mathrm{s}$ vysokou plasticitou (F7 MH) a hlína s velmi vysokou plasticitou (F7 MV). Většina náleží jílům F8 jíl s vysokou plasticitou (F8 CH), velmi vysokou plasticitou (F8 CV) až s extrémně vysokou plasticitou (F8 CE). Klasifikace zemin vychází z Casagrandeho plasticitního diagramu. Na obrázku 3 je vyznačena pozice všech analyzovaných vzorků se zařazením v rámci plasticitního diagramu. Méně zastoupené jsou jíly se střední plasticitou (F6 CI), př́ípadně jíly s nízkou plasticitou (F6 CL). Mimo diagram spadají z celého souboru dat pouze 3 vzorky s vyšším zastoupením písčité složky, jedná se o jíl písčitý (F4 CS).

$\mathrm{V}$ tabulce 2 jsou zobrazeny parametry smykové pevnosti brněnských neogenních jílů (mechanické vlastnosti charakterizující zeminu při porušení). Mechanické vlastnosti nebývají stanovovány tak často a proto se podařilo sestavit o něco menší soubor dat (desítky vzorků), ve kterém je aritmetický průměr výrazně posunut anomálními hodnotami. Proto je lepší používat pouze modus, který lépe koresponduje s histogramy četnosti.

$\mathrm{Na}$ základě principu efektivních napětí jsou rozlišeny totální parametry smykové pevnosti $c_{\mathrm{u}}, \varphi_{\mathrm{u}}$ a efektivní parametry smykové pevnosti $c^{\prime}, \varphi^{\prime}$. Všeobecně se dá usuzovat, že jíly jakožto typické soudržné zeminy budou

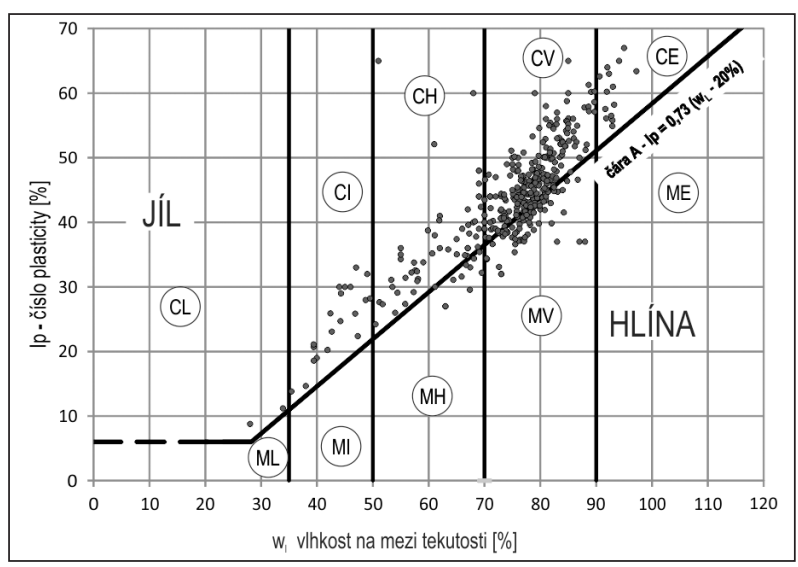

Obr. 3: Casagrandeho plasticitní diagram s vyznačenými vzorky z neogenních jílů (dle ČSN 73 6133).

Fig. 3: Casagrande plasticity chart with marked samples of Neogene clays (according to ČSN 73 6133).

mít nízký úhel vnitřního tření a vysokou soudržnost a to jak v totálních, tak i efektivních parametrech.

Neodvodněná totální soudržnost (koheze) $c_{u}$ je častá v rozsahu 40,1-150,0 kPa. Dle ČSN EN ISO 14688-2 se jedná převážně o střední až vysokou neodvodněnou smykovou pevnost (viz obr. 2d). Na dvou vzorcích z průzkumu pro Královopolský tunel (Rupp 2002) však byla dokonce zastižena i hodnota extrémně nízká $\mathrm{c}_{\mathrm{u}} \mathrm{s}$ hodnotami 4 a $6 \mathrm{kPa}$.

Úhly vnitřního tření $\varphi_{\mathrm{u}}$ dosahují dle předpokladu nižších hodnot hlavně od 0,1 do $10,0^{\circ}$ (viz obr. 2e). Dokonce u 5 vzorků dosahoval prŕmo 0 , což v teorii mechaniky zemin odpovídá ideálně soudržné, plně nasycené zemině.

V efektivních parametrech, kdy neuvažujeme vliv pórových tlaků, je efektivní soudržnost c' nižší než v totálních parametrech, obvykle 4,1-40,0 kPa. I v hodnotách efektivní soudržnosti je celkem zastoupeno 5 vzorků s hodnotou nulové soudržnosti. Úhel vnitřního tření bývá $\varphi^{\prime} 10,1-25,0^{\circ}$.

Nulová soudržnost $\left(c_{u}, c^{\prime}\right)$ ani její extrémně nízké hodnoty nejsou pro jíly typické. Možným vysvětlením těchto anomálních hodnot je bud' porušení vzorku při jeho odběru, případně odebrání vzorků oslabených předchozími svahovými pohyby, kdy stanovená pevnost odpovídá pevnosti reziduální.

\section{Inženýrskogeologické zhodnocení neogenních jílů}

Díky dobré vrtné prozkoumanosti Brna s dostatkem analýz neogenních jílů lze jejich geomechanické vlastnosti poměrně dobře posoudit. Byly zhodnoceny všechny základní popisné a fyzikální parametry, které se používají pro geotechnické výpočty.

Soubor dat však charakterizuje neogenní jíly zastižené na území města Brna bez bližšího zařažení do stupně neogénu. Lze předpokládat, že odlišné litologické vlastnosti těchto jílů se budou odrážet i v mechanických vlastnostech. Tomuto studiu je však nutno věnovat samostatný výzkum s podrobným zaměřením na jednotlivé parametry.

Neogenní jíly na území města Brna jsou soudržné, jemnozrnné zeminy s vysokým stupněm plasticity. Jedná se hlavně o zeminy s vysokou až extrémně vysokou plasticitou F7 (MH, MV) a F8 (CH, CV, CE). Plasticita jílů je 
způsobena vysokým zastoupením jílových minerálů, které zásadně ovlivňují vlastnosti těchto zemin. Obvykle se vyskytují v pevné až velmi pevné konzistenci. Neogenní jíly (zeminy tř́d F7 a F8) jsou nevhodné do násypu a nevhodné do podloží vozovky (ČSN 73 6133).

Vyšší podíl jílových expandabilních minerálů (illit/ smektit, smektit, illit, kaolinit), způsobuje objemovou nestálost jílů. Ta je zapř́činěna schopností těchto minerálů vázat do své krystalové mřižky vodu.

Vysoký obsah jílových minerálů způsobuje vysokou namrzavost těchto zemin. Vhodné je proto zakládat do větších hloubek, v nichž nedochází $\mathrm{k}$ ovlivnění základové půdy vlivem klimatických podmínek (promrzání a vysychání). Minimální doporučená hloubka založení je 1,6 m pod upraveným terénem (dle ČSN 73 1001). Pokud není základová spára uložena $\mathrm{v}$ dostatečné hloubce, může vlivem vlhkostních změn docházet k bobtnání a smrštování zeminy a tím nadzvedávání konstrukce.

Vysoká plasticita zároveň způsobuje nízkou propustnost. Praktickým di̊sledkem pro zakládání staveb je dlouhodobá konsolidace těchto zemin, která může probíhat až několik desítek let po dokončení stavby. Vzniká i vyšší pravděpodobnost nerovnoměrného sedání.

Vysoká plasticita podmiňuje vysokou stlačitelnost a proto je nutné počítat $s$ tím, že tyto zeminy jsou hodně stlačitelné.
Neogenní jíly jsou zeminy náchylné k sesouvání, v nichž vznikají zpravidla mělké smykové plochy (Šamalíková 1982). Na území města Brna je zdokumentována řada sesuvů, které zásadně porušily kvalitu těchto základových půd a bylo nutné přistoupit $\mathrm{k}$ jejich nákladné sanaci (např. sesuv u vily Tugendhat, na sídlišti v Bystrci, v Medlánkách.)

Zvýšená pozornost by měla být věnována anomálně nízkým hodnotám soudržnosti $c_{u}$ a $c^{\prime}$, které by mohly odkazovat na problémové chování jílů, které může být způsobeno právě svahovými pohyby.

Kvůli všem výše zmíněným vlastnostem je nutné tyto neogenní jíly označit jako podmínečně vhodné pro zakládání. Hlavní nepř́íznivé projevy těchto základových půd jsou vznik objemových změn v podzákladí, malá únosnost, nestejnoměrné sedání a také možnost vzniku svahových pohybů. S ohledem na všechny tyto nepř́íznivé vlastnosti je nutné v prostoru plánované výstavby provádět podrobný inženýrskogeologický průzkum vycházející z dostatku inženýrskogeologických vrtů a analýz zastižených zemin se stanovením místních charakteristik.

\section{Poděkování}

Práce byla podpořena interním projektem ČGS 390003 (Základní geologické mapování území České republiky $1: 25000$ - oblast Brněnsko). Děkuji Mgr. Lence Kociánové za vytvoření schématu karpatské předhlubnè.

\section{Literatura}

Buriánek, D. - Bubík, M. - Franců, J. - Fürychová, P. - Havlíček, P. - Gilíková, H. - Janderková, J. - Kašperáková, D. - Krejčí, O. - Krumlová, H. - Kryštofová, E. - Šrámek, J. - Müller, P. - Otava, J. - Paleček, M. - Sedláček, J. - Pecina, V. - Tomanová Petrová, P. - Večeřa, J. - Verner, K. - Vít, J. (2013): Vysvětlivky k Základní geologické mapě České republiky $1: 25$ 000, list 24-342 Brno-jih. 249 s. - MS, Česká geologická služba.

ČNI (2003): ČSN EN ISO 14688-1 Geotechnický průzkum a zkoušení - Pojmenování a zatř̌idování zemin - Část 1: pojmenování a popis. - Český normalizační institut. Praha.

ČNI (2005): ČSN EN ISO 14688-2 Geotechnický průzkum a zkoušení - Pojmenování a zatřidování zemin - Část 2: Zásady pro zatřidování. - Český normalizační institut. Praha.

ČNI (2010): ČSN 736133 Návrh provádění zemního tělesa pozemních komunikací. - Český normalizační institut. Praha.

Hanžl, P. - Baldík, V. - Bubík, M. - Buriánek, D. - Dolníček, Z. - Dvořák, I. - Fürychová, P. - Havlín, A. - Hrdličková, K. - Kociánová, L. - Konečný, F. - Krejčí, O. - Krejčí, Z. - Krumlová, H. - Kryštofová, E. - Müller, P. - Paleček, M. - Pecina, V. - Pecka, T. - Poul, I. - Rez, J. - Skácelová, D. - Skácelová, Z. - Slobodník, M. - Šrámek, J. - Tomanová Petrová, P. - Večeřa, J. - Vít, J. (2011): Vysvětlivky k základní geologické mapě České republiky 1 : 25000 24-324 Brno-sever. - MS, Česká geologická služba.

Rupp, D. (2002): Brno - VMO Dobrovského, průzkumné štoly, dílčí zpráva č. 2. - MS, Geotest.

Šamalíková, M. (1982): Základové půdy Brněnské kotliny. - In: Musil, R. (1980): Kvartér Brněnské kotliny. Sborník referátů pro XI. Kongres INQUA, 249-256, Geografický ústav ČSAV Brno.

ÚNM (1987): ČSN 731001 Zakládání staveb. Základová půda pod plošnými základy. - Vydavatelství úřadu pro normalizaci a měření. Praha. 